\title{
A Research on Sustainability Reports of Business in Terms of Corporate Social Responsibility
}

\author{
Emine ȘARDAĞI ${ }^{1}$ @ , Gül COȘKUN DEĞiRMEN²
}

\begin{abstract}
The purpose of this study is to determine, how much companies are committed to sustainability reports they publish by using content analysis method. The companies are chosen from 2019 Fortune Turkey Top 500 list, in which companies with highest net income are listed. The sample of the research consists of the top 100 companies in the list. It presents findings from an analysis of 100 companies' websites in Turkey and their sustainability reports and discusses the findings within this conceptual context. The findings of the research showed that the majority of the companies that were examined did not share their sustainability-oriented efforts on their websites. Most of the companies that shared their reports try to make their commitments towards sustainability concrete with at least one initiative. It was determined that the least mentioned element in all the themes in the reports was about the results of performance measurement. As a result, companies make a commitment and support it in an initiative, while paying less attention to sharing its results for performance measures and being less willing to do so.
\end{abstract}

Keywords: Sustainability, sustainability report, environmental sustainability, economic sustainability, social sustainability.

\section{INTRODUCTION}

The variety of social, economic, cultural and political needs and the insensible use of the resources to meet these needs, have caused the balance of resources to deteriorate and diminish. The problems faced in the world we live in do not affect only one country or region. Various attempts have been made, especially after the 1970s, with the start of a period in which life-threatening problems are now more difficult to prevent. The fact that these problems that we face have gained a global dimension rather than a local one, brings along approaches with new collaborations. This made it necessary for the institutions to pay attention to the problems of the environment they live in and to act on the basis of sustainability in economic, social and environmental issues. Expectations that were merely financial in the past were replaced by social expectations. Actually, financial expectations have not been completely lost. Instead, in the new order, it increased the chance for the competition of the businesses with a high sense of responsibility. These businesses are the ones that give social messages, that protect and look out for the environmental and social values (Kuşat, 2012: 228).

The most acceptable sustainability concept had emerged in the Brundtland Report that was published in 1987 with the term "sustainable development". Brundtland Report defined sustainable development as "development seeking to meet the needs of the present generation without compromising the ability of future generations to meet their own needs" (WCED, 1987). According to Diesendorf (2000:3), "this definition emphasises the long term aspect of the concept of sustainability and introduces the ethical principle of achieving equity between the present and future generations. The definition indicates that 'needs' include a sound environment, a just society and a healthy economy".

\footnotetext{
${ }^{1}$ Research Assistant, Uşak University, Faculty of Communication, Department of Public Relations and Advertising, Uşak, eminesardagi@gmail.com

${ }^{2}$ Assoc. Prof. Dr. Akdeniz University, Serik Faculty of Business Administration, Tourism Management, Antalya, coskungul@gmail.com (Corresponding Author)
} 
The present study aims to determine the commitments (statements) of the companies in their sustainability reports and to determine how much they are committed to these reports. In this study, the sustainability reports and information shared by the companies on their websites were evaluated by using content analysis method. Accordingly, 2019 Fortune Turkey Top 500 list, in which companies with highest net income are listed, was used. Top 100 companies from the list were chosen and information about sustainability practices on their websites were analyzed. The reports and the information were analyzed in three stages. In the first stage, it has been examined whether the companies have sustainability commitments in their reports and websites. In the second stage, the fact that how many of these commitments were concluded with at least one initiative was discussed. In the last stage, it was analyzed whether they perform performance measurements for the results of these initiatives. By this means, this research tries to reveal how many of the commitments in these reports are realized.

Studies in the field of sustainability are generally examined through their effects on financial performance. $78 \%$ of the studies revealed that there is a positive relationship between sustainability and financial performance (Alshehhi et.,2018). In these studies, research were generally carried out over sustainability reports (Weber,2017; Laskar et.,2017; Nnamani et.,2017; Lu and Taylor,2016). However, this study deals with sustainability reports from a different perspective. This study was carried out on the basis of De Grosbois' research that was conducted in 2016. De Grosbois analyzed the websites and sustainability reports of 50 cruise lines in the tourism industry. De Grosbois (2016) approached his work only in terms of tourism sector. However, in this research, the companies with highest net income from different sectors were evaluated.

The study is important in terms of revealing how much of this is put into practice, even if the companies express the protection of the environment and society at every opportunity. No other similar study was found during the research process.

The paper is organized as follows: the literature review on the sustainability and sustainability reports are analyzed in the first section. The second section provides the details of the research methodology adopted for this study. In the third section, statistical analysis results are exhibited and the paper is finalized with the conclusion section.

\section{CORPORATE SUSTAINABILITY CONCEPT AND LITERATURE REVIEW}

The concept of sustainability, which was first formally used in 1987, was included in the report titled "Limits of Growth". This report was first put forward by the Club of Rome on the challenges facing humanity in the 21st century (Meadows and Meadows, 1972 as cited in Akgül:2010). Rising popularity of the sustainability concept, awareness about the environment-development relationship and changing of the content is caused by Brundtland's "Our Common Future" report. It was presented to world public opinion in 1987 and was prepared by World Commission on Environment and Development (WCED) (Şen, et al.,2018:15). The Bruntland Commission (United Nations, 1987) defines sustainability "as meeting the current needs of present generations without compromising the ability of future generations to meet their own needs". There are different definitions in the literature about sustainable development. However, the most widely accepted definition is included in the Brundtland Report. "An important point in this definition is that future generations are accepted as stakeholders of current generations" (Çalışkan, 2014:248).

Sustainable development is used as a social concept and "corporate sustainability" is considered more as a corporate concept. The International Institute for Sustainable Development (IISD, 1992) defined the corporate sustainability concept as "adopting the preservation, maintenance and expansion of natural and human resources that will be needed in the future, while creating business strategies and activities to meet the needs of institutions and stakeholders".

Szêkely and Knirsch (2005:628) define sustainability in terms of institutions. They state that "sustainability is about creating a society in which an appropriate balance is created between economic, social and ecological goals". And for businesses, that means economic growth, shareholder value, prestige, corporate reputation, customer relations, maintaining and expanding the quality of services and product. Van Marrewijk (2003:102) as well, states that corporate sustainability means social and environmental concerns are incorporated into commercial activities and stakeholder interactions. Milne and Gray (2002) state that the concept of sustainability does not only mean the efficient allocation or use of resources, but also the fair distribution of these resources and opportunities between present and future generations. According to Fisher et. (2020:89), "business managers are becoming 
more aware that sustainability measures benefit the environment, society in general, and their own firms; at the same time, investors request businesses to behave in a sustainable way and assess the full triple bottom line".

Sustainability is an important concept because of multitude of reasons. These reasons can be listed as follows (Hitchcock \&Willard, 2009:14-16):

- Natural resources are now a limiting factor,

- Environmental issues are becoming global,

- Health concerns are rising,

- Social, environmental and economic factors are entangling, and they are creating instability,

- Energy supplies are a significant threat,

According to Costa Maynard et al (2020:1804), "even though economic growth has improved the living conditions of billions of people, globalization is causing severe environmental crises, increasingly leading to the exhaustion of nature and its natural resources". The consequences of environmental problems in the 21 st century are growing steadily. In this process, both businesses and people living in the society have great responsibilities, because nature's resources are no longer limitless. Increasing population growth brings more consumption. It causes excessive use of non-renewable resources. Another important reason is the increased demands from various stakeholder groups. These demands forced organizations to adopt some responsible management practices.

\section{Dimensions of Sustainability}

Sustainability is examined in three dimensions in the literature; environmental, economic and social (Fischer et.2020; Choi and Ng,2011; Reddy and Thomson,2015). According to the sustainability approach, these dimensions should be integrated into business strategies. It also requires reporting of the performance of business activities related to these three dimensions (Atağan, 2017:513).

The dimensions of sustainability can be briefly explained as follows:

Economic sustainability "is focused on the cost-effectiveness of all economic activities, emphasising the financial components. This dimension of sustainability at its simplest can be interpreted as how organisations stay in business" (Cozzio,2019:63). The economic dimension refers to how to use the resources of the planet and the efficient application of natural resources in a competitive environment (Bertotto et. 2014).
"Economic sustainability is directly related to both environmental and social sustainability" (Reddy and Thomson,2015). According to Caradonna (2014:13), "the economic dimension requires a system that can constantly produce goods and services, avoid excessive debt, and balance the demands of different sectors of the economy".

Environmental sustainability refers to"conserving and managing resources in such a way that the environmental damage is minimised and biological diversity and natural heritage are preserved" (Cozzio,2019:63). Environmental sustainability is one of the biggest and most important issues faced by the mankind at present. Environmental sustainability, which is not unlimited in natural resources and is related to the carrying capacity of the natural environment, is actually one of the dimensions that emerge with a greater burden on nature. The environmental dimension of sustainability is concerned with the principle of environmental integrity that requires human activities to not erode the world's land, air and water resources, and the welfare of natural systems over time.

Social sustainability: Social sustainability is a difficult dimension to define as it covers society, communities and culture (Høgevold etc.2015). Social sustainability includes"the respect of human rights, the empowerment of the local culture and the avoidance of any forms of cultural destruction" (Cozzio,2019:64). According to Choi and Ng (2011), "the social dimension of sustainability is concerned with the well being of people and communities as a noneconomic form of wealth" (p:270). Another definition of social sustainability is "the condition of a society where social tensions do not escalate but are solved in a peaceful way" (Ketschau,2017:339).

De Grosbois (2016), on the other hand, examines sustainability with five themes developed based on GRI standards which consist environmental sustainability, employment quality, diversity and accessibility, social and community well-being. The commitments put forward as a part of sustainability indicates that the initiatives that are undertaken and the performance level of these initiatives are important.

\section{Sustainability Reports}

There are different sustainability reports named such as "sustainability reports", "sustainable development reports", "corporate social responsibility reports", "corporate responsibility reports", "triple bottom line reports " and "accountability reports". Sustainability 
reports are defined by the World Business Council for Sustainable Development (WBCSD,2002:7) as "public reports that provide internal and external stakeholders with a framework for economic, environmental and social activities".

The Global Reporting Initiative (GRI), defines sustainability reports as "a report published by a company or an organization about the economic, environmental and social impacts caused by its everyday activities". According to Clarissa and Rasmini (2018) "sustainability report is a report containing non-financial information that consists economic, social and environment performance. Sustainable company is a company that not only pays attention to the benefits, but also aware about environmental and social issues around their company" (p:139).

Nowadays sustainability reporting is gaining popularity as a communication instrument between a corporation and its stakeholders (Cahyandito and Ebinger, 2005). Herremans et al. (2016) state that the concept of sustainability was developed in response to stakeholder demands. And, one of the key mechanisms for stakeholder participation is sustainability statements, usually in the form of a report. In non-financial reporting, corporate sustainability is widely accepted as a reporting tool and is conceptualized as bottom triple bottom line (TBL) reporting. This concept briefly expresses the necessity of considering and reporting the social, environmental and economic impacts of business activities as a whole. In literature, it is symbolized as "three P's": people, planet and profit (Çalışkan, 2014: 255).

Corporate sustainability reports combine the economic, environmental and social performance of an institution in a single report. Gavana et al. (2017: 12) states that sustainability reports are a way of showing that an institution's activities are in line with the system of values shared by society and thus protect socioemotional assets. Dagilienè (2014: 1660) states that the following corporate factors are effective in the development of sustainability reporting in organizations:

- Mandatory factors - the formal and informal impact of public authorities and other social forces (e.g. market regulators) on companies.

- Normative factors - impact of professional organizations on the development of sustainability reporting methodologies, standards and principles.
- Economic factors - the impact of economic changes and sustainable development. Due to economic factors, commercial companies have crossed traditional boundaries and went beyond the disclosure of financial information to shareholders and potential investors.

- Copying factors - companies tend to behave in a similar way to their successful equals. These factors are considered less important in sustainability reporting.

There are various reasons for reporting the activities of the institutions on environmental, economic and social issues. In the survey conducted by the Boston College Center for Corporate Citizenship and EY in 2013, it is found that transparency, risk management and stakeholder pressure are the top three reasons. Apart from these, there are different reasons for reporting: reputation (Farneti and Guthrie, 2009); gaining legitimacy and informing stakeholders (Mussari and Monfardini, 2010); transparency and accountability (Greco et al., 2015; Rixon, 2010); monitoring progress according to specific objectives; furthering awareness, transparency and increased reliability for broad environmental issues (Kolk, 2010).

Stakeholders pressured organizations to be more open and transparent and this pressure made it compulsory for institutions to share not only reports on their financial performance, but also reports about their social and environmental impact on society. This situation is approached by institutions and their stakeholders as part of corporate sustainability and sustainability reports are becoming increasingly important.

\section{Objectives and Benefits of Sustainability Reporting}

Global Reporting Initiative states that sustainability reports can be used for benchmarking (comparison and evaluation of sustainability performance according to laws, norms, rules, performance standards and voluntary initiatives), demonstrating (showing how the institution influences and is influenced by expectations about sustainable development), and comparing (comparing performance that covers specific times within an organization and between different organizations). Herzig and Schaltegger (2006: 302) list these objectives and the benefits of sustainability reporting as corporate legitimacy, reputation and brand value, competitive advantage, corporate performance indicator, benchmarking with competitors, internal transparency and accountability, employee motivation, internal information and control process. Sustainability 
reports are one of the tools that play an important role in changing external perceptions of the institution, initiating dialogue with stakeholders, and establishing communication and relations between the institution and its stakeholders (Bonsón and Bednárová, 2015: 183). The Global Reporting Initiative lists the internal and external benefits of sustainability reporting for businesses and organizations, as shown in the table below:

Many studies have been carried out in the literature on sustainability reporting. The focus of these studies is the impact of sustainability on financial performance. There are different results in the literature regarding the effects of sustainability and financial performance. While some studies have found that sustainability reporting has a positive effect on financial performance (Sumaryati and Rohman,2019; Whetman,2017;Aggarwal;2013) others state that it has a negative effect (Asuquo et al.,2018; Tarigan and Semuel,2014).

A comprehensive study on the results on this subject has been done by Alshehhi et al. in 2018. Alshehhi et.al. (2018) examined 132 articles published in the best journals in their content analysis study. As a result of the research, they found that $78 \%$ of the articles reported a positive relationship between corporate sustainability and financial performance. It is also stated that $6 \%$ of the articles show a negative effect between sustainability and financial performance. Clarissa and Rasmini (2018) also analyzed the effect of sustainability reports on financial performance by observing each aspect of the sustainability reports. The results of the research, social and environmental performance disclosure has a positive effect on financial performance. However, economic performance disclosure has been found to have a negative impact on financial performance. Similarly, Al Matarneh (2019) examined the impact of the environmental, social and economic dimensions on the quality of financial disclosure. The results of the questionnaire indicate that social and economic dimensions are important factors that affect the quality of financial disclosure. Also in the study, it is revealed that "social dimension" had the highest mean score, followed by "economic dimension" and "environmental dimension".

\section{METHODOLOGY}

The present study aims to determine the commitments (statements) of the companies in their sustainability reports and to determine how much they are committed to these reports. The results of the study are not only important for seeing companies' commitments for sustainability practices. It is also important to find out to what extent they have realized these commitments. The study is based on this perspective. Accordingly, the study tries to answers the research questions below:

RQ 1:Do companies make target-specific commitments in sustainability activities?

RQ 2:Do companies have at least one attempt to achieve this goal?

$\mathrm{RQ}$ 3:Is, at least, one performance measurement performed to address companies'

contribution to the target?

Table 1: The internal and external benefits of sustainability reporting for businesses

\begin{tabular}{ll}
\hline \multicolumn{1}{c}{ Internal Benefits } & External Benefits \\
\hline - Increasing risks and opportunities, & Alleviating or reversing negative environmental, \\
- Emphasizing the link between financial and non-financial & social and governance impacts \\
performance, & Improving reputation and brand loyalty \\
- Influencing long - term management strategy, policy and & - Enabling external stakeholders to understand \\
business plans & the true value of the institutions, its tangible and \\
- Simplifying processes, reducing costs and increasing & intangible assets \\
productivity & Demonstrating how the institution influences and \\
- Comparing and evaluating sustainability performance & is influenced by expectations about sustainable \\
voluntary initiatives & development \\
- Avoiding public environmental, social and governance & \\
failures & \\
Comparing internal and inter-institutional performance & \\
\hline
\end{tabular}

Source: Adapted from Benefits of Reporting.

https://www.globalreporting.org/information/sustainability-reporting/Pages/reporting-benefits.aspx (Accessed on 11.06.2019) 
In this study, which examines the commitments and initiatives of companies in their sustainability reports, descriptive research design is included. In descriptive design, the concept of descriptor describes what a situation, condition, man, organized activity, communication process and policy is, and tries to clarify these concepts. (Erdoğan, 2007: 138). In this study, content analysis method was used to reach the data. Binark (2014) stated that the main purpose of content analysis is to investigate how often the characteristics in a text are repeated, how they are presented, and to determine the formal characteristics of the messages. The reason of using content analysis method in the study is to find out how often the commitment, initiative and performance measures related to sustainability themes are observed in the information of the Fortune 500 companies in their reports and websites.

\section{Population and Sample}

Population of the study is consisted of companies in 2019 Fortune 500 in which largest companies of Turkey are listed. And the sample group is determined as the first 100 companies in this list. As part of the study, sustainability reports and information on official websites of selected companies between 1-9 July 2019 were examined. The findings of the study are limited to the information and reports shared by the companies on their websites on 1-9 July 2019. In addition, reviews were made based on the most recent reports published by companies regardless of year.

\section{Collection of Data}

The data collection process was carried out in two stages. In the first stage, companies in the sample group were listed and their website addresses were confirmed. Afterwards, the information and reports of these companies under the heading of sustainability on their websites were examined. Whether the sustainability information is available on the websites was checked, and quantitative data such as which sections are presented on the website, which year the last published report belongs to, how many reports were published and the number of pages were evaluated.

In the second stage of the study, the latest reports published by the companies and the information on the websites were reviewed. When the companies' websites are examined, it is seen that some of them publish their sustainability activities in a year-based report and some of them share detailed information on sustainability on their websites. For this reason, in order to provide comprehensive data to the study, it was considered appropriate to include both formats that are under the heading of sustainability.

Report and information contents of the companies which offer sustainability reports and information about sustainability on their websites are analyzed based on "Corporate social responsibility reporting in the cruise tourism industry: a performance evaluation using a new institutional theory based model" research that is written by De Grosbois (2016). In this study, De Grosbois (2016) tries to explain, based on Global Reporting Initiative (GRI) standards, sustainability and corporate social responsibility reporting behavior with the model created in terms of institutional theory. "Five corporate social responsibility themes consisting of environmental sustainability, employment quality, diversity and accessibility, social and community well-being that are developed based on GRI standards and 36 targets under these themes" in De Grosbois'study underlie our research. It has been analyzed whether the targets determined accordingly are included as commitments in the reports and websites of the companies. Also, it has been examined whether or not they have performed at least one initiative for these commitments and whether they have been measured or not. For each company that publishes reports and provides information on sustainability on the website, a three leveled coding has been done through five social responsibility themes and 36 target.

Coding of the reports in the study was performed in conjunction by the researchers. Firstly, two researchers conducted a preliminary study and evaluated 5 companies separately, then ensured reliability between the encoders by checking the similarity of the data obtained. Then the research form was applied to the whole sample group. The data obtained were evaluated with SPSS 25 package program. In the first part of the study, frequency analysis of the data was done. In the section where data on social responsibility themes and targets were evaluated, multiple response analysis was performed.

\section{FINDINGS}

\section{Results from Websites for Sustainability Information}

In this part of research, these are the things that are primarily analyzed: the sectoral distribution of top 100 companies in 2019 Fortune 500 Turkey list, information on sustainability at companies' websites, sections of this information on the website, number of businesses 
reporting and providing information on sustainability, number of sustainability reports by years, number of reports prepared in accordance with the Global Reporting Initiative, abbreviated as GRI, and number of matrix to "scale priority issues" in reports.

The sectoral distribution of the companies in the study is based on the sectors specified in the Fortune list. In the Table 2 above, it is seen that companies from 33 different sectors are ranked. Looking at the sectoral distribution of the top 100 companies in the 2019 Fortune 500 Turkey list, it is seen that the highest ratio (12\%) belongs to the energy sector. "Metal casting and processing" is the second sector in the list. And "production and distribution of petroleum and derivatives", and "construction contracting" are the other areas with the highest proportion.

The "Others" part of the examined sectors consists of companies in 11 different sectors, each of which is $1 \%$. These sectors can be listed as follows; heavy industry construction and contracting, information and communication services, iron and steel trade, natural and processed solid fuel, economic state organization, linen fiber and fiber yarn, machinery and equipment, medical and pharmaceutical, marble, metals and ores, metal refinery services.

Table 2: Number of Companies Examined by Sectors

\begin{tabular}{|c|c|c|}
\hline Sector & Number (n) & $\%$ \\
\hline Energy/Petroleum and energy & 12 & 12 \\
\hline Metal casting and processing & 9 & 9 \\
\hline Manufacture and distribution of petroleum and derivatives & 7 & 7 \\
\hline Construction contracting & 7 & 7 \\
\hline Retail trade stores & 6 & 6 \\
\hline Travel and transportation services & 5 & 5 \\
\hline Grain, milk, meat and seafood & 5 & 5 \\
\hline Industrial food manufacturing & 5 & 5 \\
\hline Storage, transport and logistics services & 4 & 4 \\
\hline Chemical substances & 4 & 4 \\
\hline Vehicles and equipment manufacturing and maintenance & 4 & 4 \\
\hline Electronics and telecommunications & 3 & 3 \\
\hline Computer, software and office machines & 2 & 2 \\
\hline Glass and glass products & 2 & 2 \\
\hline Non-ferrous metals & 2 & 2 \\
\hline Household electrical appliances & 2 & 2 \\
\hline Ready-wear, underwear and sportswear & 2 & 2 \\
\hline Jewelry & 2 & 2 \\
\hline Sale and service of motor vehicles & 2 & 2 \\
\hline Plastics \& Rubber & 2 & 2 \\
\hline Wholesale food, drinks and cleaning products & 2 & 2 \\
\hline Others & 11 & 11 \\
\hline Total & 100 & 100 \\
\hline
\end{tabular}

Table 3: Existence of Sustainability Information on the Website

\begin{tabular}{lcc}
\hline & Number (n) & $\%$ \\
\hline Sustainability report shared & 29 & 29,6 \\
Information only shared on the website & 16 & 16,3 \\
No information shared & 53 & 54,1 \\
\hline
\end{tabular}


While examining the results about the existence of sustainability information on the websites, it was found that 3 companies in the top 100 on the 2019 Fortune 500Turkey list referred to the same website. While these companies were identified as "Trakya Cam Sanayi", "Soda Sanayi" and "Anadolu Cam Sanayi", it was seen that these companies were included in the Şişecam Group and published a single report. Therefore, these three companies are considered as one company. As a result, the number of companies examined is 98 and the number of reports reached is 29 . In this respect, the data obtained in the next section were evaluated as total of 45 companies, including 29 companies that published sustainability reports on their websites and 16 companies that did not have reports on their websites but shared information on this issue. When the websites of 98 companies were examined, it was found that more than half (54.1\%) did not share any information reports about sustainability on their websites. On the other hand, while $29.6 \%$ presented sustainability information as a report, $16.3 \%$ shared information in different sections of their websites under the heading of sustainability.

Table 4: Section of the Website that Includes Sustainability Information

\begin{tabular}{lcc}
\hline Section & Number (n) & $\%$ \\
\hline Sustainability Section & 30 & 66,7 \\
About Us -Corporate Section & 9 & 20 \\
Investor Relations Section & 4 & 8,9 \\
Others & 2 & 4,4 \\
Total & 45 & 100,0 \\
\hline
\end{tabular}

When the information on the sustainability of 45 companies is examined in terms of the sections on their web sites, it is found that $66.7 \%$ of the companies present their activities that contribute to society under the headline of "sustainability". 20\% share information on their About Us-Corporate section. And 8,9\% share information to their stakeholders in Investor Relations section.

When the number of pages of these 29 companies' reports were examined, it was seen that the majority (14 companies - 48.3\%) had 51-99 pages. There are only 4 companies that published 100 pages or more. The number of companies that published 50 pages or less is 11. Looking at the distribution of 29 reports published as of July 1-9, 2019, 16 companies shared sustainability reports in 2018. In 2019, only one company published a report. The number of companies that published reports in 2017 is 9 . And in 2016, there is only one company report. In addition, two companies shared their reports in 2014-2015 and 2016-2017. In this respect, it is seen that the most reports were shared in 2018. When we look at the frequency of the reports, it was found that 17 companies shared 1-5 reports on their websites and 10 companies shared 6-10 reports. There are only 2 companies that have published more than 10 reports.

Various globally accepted standards are used in the preparation of sustainability reports. Institutions share the information that should be based on these standards when preparing sustainability reports.

In this sense, one of the standards used in sustainability reporting is the Global Reporting Initiative, abbreviated as GRI.

Table 5: Number of Pages, Year and Frequency of Publication in the Sustainability Reports Presented by the Companies

\begin{tabular}{|c|c|c|c|}
\hline & & \multirow{3}{*}{$\begin{array}{c}\text { Number (n) } \\
11\end{array}$} & \multirow{3}{*}{$\begin{array}{c}\% \\
37,9\end{array}$} \\
\hline & & & \\
\hline \multirow{3}{*}{ Page Number } & 50 page or under & & \\
\hline & between 51-99 pages & 14 & 48,3 \\
\hline & 100 page or over & 4 & 13,8 \\
\hline \multirow{4}{*}{ Report Year } & 2019 & 1 & 3,4 \\
\hline & 2018 & 16 & 55,1 \\
\hline & 2017 & 9 & 31 \\
\hline & 2016 & 1 & 3,4 \\
\hline \multirow[t]{3}{*}{ Frequency of Publication } & $1-5$ & 17 & 58,6 \\
\hline & $6-9$ & 10 & 34,5 \\
\hline & 10 and over & 2 & 6,9 \\
\hline \multirow{2}{*}{$\begin{array}{l}\text { Declaration of adherence to } \\
\text { GRI standards }\end{array}$} & Yes & 27 & 93,1 \\
\hline & No & 2 & 6,9 \\
\hline
\end{tabular}


Founded in 1997 with the support of the United Nations Environment Program, GRI offers internationally recognized criteria that help organizations to understand and transfer their impact on society. Following this initiative, the Sustainability Reporting Guide was published and efforts were made to encourage sustainability reports. Institutions evaluate their environmental, social and economic impact on society within the framework of these established standards and share the results they obtained. The number of those who declare that their reports have been prepared in accordance with the basic content of GRI standards is 27 . In this respect, it can be said that almost all of the companies that publish reports have information about the existence of such a standard and consider these standards while preparing their report. In the reports of the companies, it is stated that there is a committee for sustainability studies composed of authorized persons within the company. The committee establishes a scaling matrix (low-high priority) by identifying priority issues on sustainability studies. Accordingly, when the information of the companies about this issue was evaluated, it was determined that 14 companies formed a matrix of scaling priority issues in their reports and 5 companies listed them as subject priorities. 10 companies did not share any information regarding their priorities in the reporting process.

Looking at the distribution of the five main sustainability themes in the reports and websites of the companies examined, it is seen that the companies share their knowledge about commitments to the highest employment quality by $36.6 \%$ in the reports and websites. While the second place was shared by the themes of environmental sustainability $(31.1 \%)$ and economic prosperity (31.1\%); it is determined that by $23 \%$ of the commitments mentioned in reports and websites, the least mentioned is the main theme of diversity and accessibility. However, although the companies examined share information about their commitments and initiatives, it is seen that the infor- mation on performance measurements in all themes is the least mentioned theme in reports and websites.

\section{Sustainability Themes, Commitment, Initiative, Performance Measurement Findings}

In this part of the study, it has been investigated whether there are five corporate social responsibility themes and commitments related to 36 targets under these themes in the information and reports of the companies. At the same time, the existence of information about the initiatives and performance measurements of these undertakings were investigated. Accordingly, three levels of coding were realized on 5 themes and 36 targets.

Coding was evaluated by multiple response analysis in SPSS program. Because of the multiple responses, the number of answers is not equal to the number of samples. Thus the resulting percentage of answers can exceed $100 \%$ and the number of samples exceeds the specified sample volume. Within the scope of multi-response analysis, the research of 45 companies providing information on sustainability and publishing sustainability reports on the website was conducted in the following order:

- First, the number of companies that made a commitment is examined.

- Afterwards, of those that made a commitment, it was examined how many gave information about at least one initiative they undertook related to the commitment they have made.

- In the last stage, it was examined how many of the people who shared the information about the initiative gave information about the performance measurement.

As a result of the research, the results related to the objectives under the themes of environmental sustainability, employment quality, diversity and accessibility, social and community well-being are as follows:

Table 6: General Distribution of Sustainability Themes

\begin{tabular}{lcccc}
\hline Themes/Goal* & $\begin{array}{c}\text { Commitment/ } \\
\text { goal statement }\end{array}$ & Initiatives & $\begin{array}{c}\text { Performance } \\
\text { Measurements }\end{array}$ & Unspecified \\
\hline Employment Quality & $36 \%$ & $26,3 \%$ & $13,3 \%$ & $24,4 \%$ \\
Environmental Sustainability & $31,1 \%$ & $25,1 \%$ & $17,6 \%$ & $26,3 \%$ \\
Economic Prosperity & $31,1 \%$ & $25,1 \%$ & $17,6 \%$ & $26,3 \%$ \\
Social and Community Well-Beıng & $28,4 \%$ & $26,0 \%$ & $16,1 \%$ & $29,5 \%$ \\
Diversity and Accessibility & $23,0 \%$ & $20,9 \%$ & $11,8 \%$ & $44,2 \%$ \\
\hline
\end{tabular}

*more than one option is selected. 
Table 7: Environmental Sustainability Theme and Objectives Research Results

\begin{tabular}{|c|c|c|c|c|}
\hline Sub Themes * & $\begin{array}{l}\text { Commitment/ } \\
\text { goal statement }\end{array}$ & Initiatives & $\begin{array}{l}\text { Performance } \\
\text { Measurements }\end{array}$ & Unspecified \\
\hline $\begin{array}{l}\text { Mitigate the impacts of climate change / reduce } \mathrm{CO} 2 \text { or } \\
\text { greenhouse gases emissions }\end{array}$ & $39(86,7 \%)$ & $30(66,7 \%)$ & $21(46,7 \%)$ & $5(11,1 \%)$ \\
\hline Waste reduction and recycling & $39(86,7 \%)$ & $36(80 \%)$ & $29(64,4 \%)$ & $5(11,1 \%)$ \\
\hline Reduce energy consumption & $35(77,8 \%)$ & $30(66,7 \%)$ & $27(60 \%)$ & $8(17,8 \%)$ \\
\hline Reduce water consumption & $34(75,6 \%)$ & $30(66,7 \%)$ & $27(60 \%)$ & $10(22,2 \%)$ \\
\hline $\begin{array}{l}\text { Use renewable energy sources / Produce own clean } \\
\text { energy }\end{array}$ & $28(62,2 \%)$ & $21(46,7 \%)$ & $16(35,6 \%)$ & $15(33,3 \%)$ \\
\hline $\begin{array}{l}\text { Contribute to biodiversity conservation and habitat } \\
\text { restoration }\end{array}$ & $22(48,9 \%)$ & $19(42,2 \%)$ & $10(22,2 \%)$ & $23(51,1 \%)$ \\
\hline Responsible design, construction and renovations & $20(44,4 \%)$ & $19(42,2 \%)$ & $7(15,6 \%)$ & $24(53,3 \%)$ \\
\hline Reduce air pollution and fuel use & $15(33,3 \%)$ & $11(24,4 \%)$ & $5(11,1 \%)$ & $29(64,4 \%)$ \\
\hline Preservation of non-renewable resources & $15(33,3 \%)$ & $6(13,3 \%)$ & $3(6,7 \%)$ & $30(66,7 \%)$ \\
\hline Reduce water pollution & $10(22,2 \%)$ & $8(17,8 \%)$ & $5(11,1 \%)$ & $35(77,8 \%)$ \\
\hline Reduce noise & $5(11,1 \%)$ & $2(4,4 \%)$ & - & $40(88,9 \%)$ \\
\hline
\end{tabular}

* more than one option is selected.

The objectives set under the name of environmental sustainability and the data obtained related to these objectives in order to mitigate the negative impacts of the companies on the environment in their community activities are shown in Table 7. Looking at the table; reducing the effects of climate change, waste reduction and recycling is among the most promised issues of the companies. Accordingly, $86,7 \%$ of the companies have sustainability reports and commitments in their websites related to mitigating the effects of climate change. While $66,7 \%$ of the companies that made commitment to climate change stated that they have made at least one attempt to reduce this effect; $46,7 \%$ of those made performance measurements in terms of their contribution to society. It is stated that companies' initiatives to reduce climate change include initiatives to mitigate the effects of greenhouse gas, conducting emission measurements and analyzing obtained measurements. In performance measurement, emission measurement results and greenhouse gas reduction rates obtained during the initiatives taken throughout the year are shared.

Other issues frequently mentioned by companies in their environmental sustainability reports are commitments to reduce waste and to recycle with $86,7 \%$ and reducing energy consumption with $77,8 \%$. It was determined that $80 \%$ of the companies participating in the research made initiatives on waste reduction and recycling while $64.4 \%$ performed performance measurements. Among the initiatives of companies in waste reduction and recycling, it is stated that in order to prevent wastes from entering the nature, they take initiatives such as separation from source, temporary storage and recycling or disposal. In the reports, the performance measurements related to this, the number and rates of waste during the year and the data obtained from their recycling are shared. It is determined that while $66.7 \%$ of the companies committed to reducing energy consumption talk about their initiatives, $60 \%$ perform performance measurement. It is stated that the energy management system is in line with the Energy Management System studies and the projects developed within this scope are mentioned. With the measurements related to this, the results of the projects are shared. It has been determined that the theme with the least commitment made by the companies in their reports and the content they share for sustainability studies on their websites is the reduction of noise with $11.1 \%$. Only 5 of the companies surveyed made a commitment to reduce noise in the environment in which they operate; while only 2 (4.4\%) took initiatives in this direction. However, it was found that none of the companies surveyed performed any performance measurement towards reduction of noise. 
Table 8: Employment Quality Theme and Objectives Research Results

\begin{tabular}{|c|c|c|c|c|}
\hline Sub Themes * & $\begin{array}{l}\text { Commitment/ } \\
\text { goal Statement }\end{array}$ & Initiatives & $\begin{array}{l}\text { Performance } \\
\text { Measurements }\end{array}$ & Unspecified \\
\hline Create a safe work environment & $41(91,1 \%)$ & $33(73,3 \%)$ & $22(48,9 \%)$ & $4(8,9 \%)$ \\
\hline Employee well-being, healthy working environment & $33(73,3 \%)$ & $13(28,9 \%)$ & $3(6,7 \%)$ & $12(26,7 \%)$ \\
\hline Ensure non-discrimination (equal opportunities) & $33(73,3 \%)$ & $21(46,7 \%)$ & $12(26,7 \%)$ & $12(26,7 \%)$ \\
\hline Provide opportunities for learning and development & $33(73,3 \%)$ & $29(64,4 \%)$ & $24(53,3 \%)$ & $11(24,4 \%)$ \\
\hline Provide opportunities for career advancement & $25(55,6 \%)$ & $20(44,4 \%)$ & $8(17,8 \%)$ & $21(46,7 \%)$ \\
\hline Increase employee empowerment / feedback & $25(55,6 \%)$ & $20(44,4 \%)$ & $14(31,1 \%)$ & $20(44,4 \%)$ \\
\hline Provide fair wages and benefits & $24(53,3 \%)$ & $13(28,9 \%)$ & $1(2,2 \%)$ & $21(46,7 \%)$ \\
\hline Employee assistance programs & $20(44,4 \%)$ & $17(37,8 \%)$ & $4(8,9 \%)$ & $23(51,1 \%)$ \\
\hline Employee performance awards & $18(40 \%)$ & $15(33,3 \%)$ & $6(13,3 \%)$ & $24(53,3 \%)$ \\
\hline Providing work/life balance policies & $13(28,9 \%)$ & $13(28,9 \%)$ & $4(8,9 \%)$ & $32(71,1 \%)$ \\
\hline
\end{tabular}

*more than one option is selected.

Table 8 shows the commitments determined for the employees, which are defined as the main force behind the success of the companies. According to this table, the theme that has the most amount of commitment in the companies' reports is creating a safe working environment for employees. It was determined that $91,1 \%$ of the companies surveyed promised to provide a safe work environment for their employees whom they considered to be one of their most important key stakeholders, while $73,3 \%$ made initiatives related to this, and $48,9 \%$ performed performance measurements. At this point, some of the most frequently used initiatives by companies is providing safety training exercises in the workplace and obtaining certification by applying to certification bodies. In the performance measurements, information regarding the accident, loss rates and the number of people / hours participating in the training exercises they organized in the year that the report was published is shared.

Another issue that $73,3 \%$ of the companies examined in the study have undertaken is to provide equal opportunity to their employees and to not discriminate between employees. It is also observed that $46,7 \%$ of those who declare that they provide equal opportunity among the employees state that they have taken initiatives for this, while $26.7 \%$ share the performance measurements for the results of these initiatives. The most emphasized issues of equal opportunity among companies that do not discriminate among employees on the basis of race, gender, nationality, political thought, religion and language are that they try to include women's employment equally in the working environ- ment, support women's participation in business life and place this at the center of human resources policies. It is stated that they evaluate the results obtained for their initiatives in this regard according to the increase in the number of female employees and their ratio in the number of employees.

Another commitment related to employees is to provide fair wages. It is stated that $53,3 \%$ of the companies surveyed adopt an equal wage to equal work policy in line with the job evaluation and grading principle and market researches within the company and that employee wages are determined depending on the positions. There is only one company that performs performance measurement in this regard and shares its performance assessment in years of wage increase in its reports.

Among the companies surveyed, $44,4 \%$ made commitments to provide employee assistance programs to their employees, and $37.8 \%$ of them talk about their initiatives towards these commitments. The rate of those who measure the results of these initiatives is $8,9 \%$. The assistance programs provided to the employees in the reports of the companies include private health-pension insurance, gift packages, food packages, food and transportation, and seniority awards. In addition, the results of the survey conducted for employee satisfaction are shared and it is stated that regulations are made in line with the demands of the employees. Although the number of companies performing performance measurement in this regard is small, information on the number of people benefiting from these rights during the year was shared in performance measurements. 
The issue with least amount of commitments in the company's reports is the statements towards ensuring work/life balance of employees. Only $28,9 \%$ of the companies make commitments to ensure the work/ life balance of their employees and only $8,9 \%$ share information about the results of these initiatives. It was determined that most of the opportunities provided for the work/life balance of the employees include breastfeeding hour, free nursery, etc. applications for mothers. For this purpose, data on how many employees benefit from these rights are shared during the performance measurement.

The information obtained from the shares made by companies on sustainability towards diversity and accessibility is shown in Table 9. In this respect, one of the subjects with the highest commitment is towards accessibility for employees with $46,7 \%$. While all of the companies that made commitments talk about their initiatives, only $17,8 \%$ performed a performance measurement. Among the initiatives undertaken by the companies surveyed in terms of accessibility for their employees, it is stated that there are initiatives such as communication channels created for employees to connect with the company, practices where employees can share their suggestions, complaints and ideas, and open notification channels. In performance measurement, information about how many times employees used these channels and how many problems were solved at this point were shared. Similarly, initiatives have been taken for the communication channels that enable them to reach the company for customers and suppliers, and even various applications and portals offered by the company are mentioned. At this point, the communication channels they use for both internal and external stakeholders and their frequency of use are among the data shared in line with performance measurement.

In terms of diversity both for employees and suppliers, it has been determined that the companies examined have commitments to provide diversity in terms of human resources and suppliers in domestic and abroad according to their field of activity and take initiatives to do so. Especially the number of suppliers domestic and abroad, and the distribution of employees in this direction are among the topics shared under this title. Another issue that companies share in diversity is that they also try to contribute to the employment of people with disabilities.

Table 9: Diversity and Accessibility Theme and Objectives Research Results

\begin{tabular}{lcccc}
\hline Sub Themes* & $\begin{array}{c}\text { Commitment/ } \\
\text { goal statement }\end{array}$ & Initiatives & $\begin{array}{c}\text { Performance } \\
\text { Measurements }\end{array}$ & Unspecified \\
\hline Accessibility for employees & $21(46,7 \%)$ & $21(46,7 \%)$ & $8(17,8 \%)$ & $22(48,9 \%)$ \\
Accessibility for suppliers and partners & $20(44,4 \%)$ & $19(42,2 \%)$ & $8(17,8 \%)$ & $25(55,6 \%)$ \\
Accessibility for customers & $18(40 \%)$ & $18(40 \%)$ & $13(28,9 \%)$ & $27(60 \%)$ \\
Increase diversity in workforce & $11(24,4 \%)$ & $6(13,3 \%)$ & $5(11,1 \%)$ & $33(73,3 \%)$ \\
Increase diversity among suppliers and partners & $6(13,3 \%)$ & $5(11,1 \%)$ & $5(11,1 \%)$ & $39(86,7 \%)$ \\
\hline
\end{tabular}

*more than one option is selected.

Table 10: Social and Community Well-Beıng Theme and Objectives Research Results

\begin{tabular}{|c|c|c|c|c|}
\hline Sub Themes* & $\begin{array}{l}\text { Commitment/ } \\
\text { goal statement }\end{array}$ & Initiatives & $\begin{array}{l}\text { Performance } \\
\text { Measurements }\end{array}$ & Unspecified \\
\hline $\begin{array}{l}\text { Social assistance for local or global community (donation, } \\
\text { employee volunteering, scholarship, philanthropy,etc) }\end{array}$ & $29(64,4 \%)$ & $27(60 \%)$ & $21(46,7 \%)$ & $15(33,3 \%)$ \\
\hline $\begin{array}{l}\text { Raise employee awareness of and involvement in } \\
\text { sustainable development issues }\end{array}$ & $26(57,8 \%)$ & $21(46,7 \%)$ & $13(28,9 \%)$ & $18(40 \%)$ \\
\hline Responsible products/healthy product choices & $24(53,3 \%)$ & $23(51,1 \%)$ & $11(24,4 \%)$ & $20(44,4 \%)$ \\
\hline $\begin{array}{l}\text { Raise, customer and/or public awareness of and } \\
\text { involvement in sustainable development issues }\end{array}$ & $22(48,9 \%)$ & $21(46,7 \%)$ & $12(26,7 \%)$ & $21(46,7 \%)$ \\
\hline Safe environment for customers and employees & $20(27,8 \%)$ & $17(23,6 \%)$ & $11(15,3 \%)$ & $24(33,3 \%)$ \\
\hline $\begin{array}{l}\text { Heritage and local culture/traditions protection and } \\
\text { preservation }\end{array}$ & $9(20 \%)$ & $8(17,8 \%)$ & $5(11,1 \%)$ & $36(80 \%)$ \\
\hline
\end{tabular}

*more than one option is selected. 
The information obtained from the shares of the companies on the social contribution towards sustainability is shown in Table 10. While companies carry out their commercial activities, they continue to engage in activities that will serve the society in which they live. Among the companies' commitments to contribute to the society they live in, in their reports and sharing, the applications that are described as social assistance for local or global community come first. At this point, $64,4 \%$ of the companies reported commitments on this issue, while $60 \%$ of the companies implemented these initiatives. When the share of performance measurements of these applications is examined, it is seen to be $33,3 \%$. Donations, sponsorships, practical training exercises, information on developing vocational training and charitable activities are shared among the social assistance provided by companies to the society. In performance measurement, donations made during the year, the amount of scholarship given information etc. is shared.

The issue of sustainability gains importance not only by the work of the top management, but also by the inclusion of employees in this understanding. While $57,8 \%$ of the companies made commitments to raise employee awareness and involvement in sustainable development issues, $46,7 \%$ took initiatives about this, and $28,8 \%$ made performance measurement. In order to ensure the participation of the employees in this direction, it is mentioned that they have benefited from voluntary activities by allocating time to various social issues within working hours, collective tree-sapling planting activities and awareness training exercises given about sustainability. In the performance measurement, information on how many employees participated in voluntary activities during the year, number of tree-seedlings planted with employees as well as the number of person hours of awareness-raising training exercises are shared.
Protection and preservation of heritage and local culture-traditions is the subject with least commitments under this title. While $20 \%$ of the companies committed to the protection of the heritage and culture of the society in which they live, $17.8 \%$ were found to be making initiatives. It is stated that among the initiatives of the companies in line with this objective, there are initiatives such as sponsoring archaeological studies, supporting excavation and restoration works. In performance measurement, information is shared about the amount of support they give to these studies and how many studies are conducted in this direction.

Undoubtedly, one of the main priorities of companies is to create value and increase the welfare level by supporting the economic development of the society in which they live. The information obtained from the shares of the companies on economic contribution is shown in Table 11. One of the issues in which companies contribute to their economic activities is to support to the local economy. At this point, it was determined that $64,4 \%$ of the companies made commitment to support the local economy in their activities. It was found that the rate of companies making initiatives in this direction was $51,1 \%$ and the rate of those performing performance measurement was $44,4 \%$. Among the initiatives that companies use to support the local economy and reduce external dependence are local supply chain practices in the process of purchasing goods and services, supporting local products and manufacturers, local business partnerships and so on. It has been determined that these initiatives contribute to the strengthening of the local economy. Performance measurements related to this are shared with the number of local suppliers during the year, their economic indicators, and the support they provide to the local producer.

Table 11: Economic Prosperity Theme and Objectives Research Results

\begin{tabular}{lcccc}
\hline Sub Themes* & $\begin{array}{c}\text { Commitment/ } \\
\text { goal statement }\end{array}$ & Initiatives & $\begin{array}{c}\text { Performance } \\
\text { Measurements }\end{array}$ & Unspecified \\
\hline Supporting the local economy & $29(64,4 \%)$ & $23(51,1 \%)$ & $20(44,4 \%)$ & $14(31,1 \%)$ \\
Sustainable supply chain & $26(57,8 \%)$ & $24(53,3 \%)$ & $17(37,8 \%)$ & $17(37,8 \%)$ \\
Cooperation with industry and public sector & $26(57,8 \%)$ & $24(53,3 \%)$ & $13(28,9 \%)$ & $18(40 \%)$ \\
Quality / local employment creation & $23(51,1 \%)$ & $13(28,9 \%)$ & $11(24,4 \%)$ & $22(48,9 \%)$ \\
\hline
\end{tabular}

*more than one option is selected. 
The companies act in accordance with the sustainability approach in the way of doing business with the suppliers they work with and undertake to work with institutions that have this perspective in the supplier selection. In the selection of suppliers, companies state that they implement supply chain implementations within the framework of their own policies, quality, and standards. At this point, $57,8 \%$ of the companies examined stated that they act in line with the sustainability policy in supplier preferences and talk about supplier evaluation processes. While $53,3 \%$ of the companies express their initiatives for this, $37,8 \%$ share their knowledge about performance measurement. Among the initiatives carried out in this direction, it is stated that the companies determine certain quality and standards in procurement and services through the supply chain committees established within their own bodies, and they also evaluate the supplier's compliance with environmental, social and ethical standards. In the procurement process, it is stated that local suppliers are preferred among the suppliers in compliance with the specified standards. In the performance measurements at this point, the information obtained from the audits performed by the committees they create are shared, and information is provided on the number of those who cannot meet the conditions determined in the supplier audit process.

In addition to the practices aimed at supporting the local economy, the commitment of companies to create local employment is another theme encountered in the reports. At this point, it was found that $51,1 \%$ of the companies made commitment to support local employment and create local employment, 28,9\% had made an initiative and $24,4 \%$ performed performance measurement. It is stated that the initiative of the companies in this regard is to give priority to providing employment to the people of the region. In the performance measurement of the information shared on this subject, information on the amount of employment provided to the people of the region is included according to the field in which the entity operates.

\section{CONCLUSION}

At a time when the world is changing, with climate change affecting the whole world, water resources constantly decreasing, and energy consumption gradually increasing, it has become important for institutions to do something for the society they live in. Being aware of the fact that they shape the future with the activities they perform, institutions are obliged to act in consideration of their social and environmental impacts for the society. In fact, our starting point in this study was to show whether the reports really reflect the truth, and how much of this was put into practice even if the companies expressed about the protection of the environment and society at every opportunity. Therefore, this study which is based on the commitments of the 100 companies included in Fortune 500 in accordance with the sustainability reports and information they share, is in fact important in terms of revealing how much of these commitments resulted in an initiative and how much is being measured accordingly. The results of the study showed that in fact, companies take care to make at least one initiative towards the targets they have committed. When the sustainability themes are evaluated in general, there appear to be no big differences between the commitments and the initiative rates.

Determining the universe and sample within the scope of the study, Fortune 500 Turkey is one of the most respected lists of the companies with the highest net income domestically. Each year, companies are working to be included in these lists. Unfortunately, a surprisingly large proportion $(54,1 \%)$ of the companies surveyed with the highest income do not share any information on their sustainability activities. From this point of view, it is important that these companies, who can contribute greatly to the realization of the works that will play an important role in the change of society, should do something for the society and share it with the future generations.

The results obtained from the research show that there is a difference between the previous studies. When we look at the distribution of the 5 main sustainability contacts determined in the reports and websites of the companies examined, it is seen that the companies share their information on the commitments in terms of employment quality with the highest rate of $36.6 \%$. Therefore, it can be said that companies clearly share detailed information in order to attract more qualified workforce to their own companies. In the study of De Grosbois (2016), which is the basis of the research, it was revealed that the most mentioned theme in the reports of the examined companies was the environmental sustainability theme with $76 \%$. In our study, it was revealed that the commitments for the environmental sustainability theme was the second most mentioned theme in the reports. Another difference emerged in the theme of employment quality. 
The quality of employment theme is one of the least mentioned in De Grosbois' work. However, in our study, it is seen that the quality of employment is the most mentioned theme in the reports of the companies. It can be said that the sector diversity of companies in the sample is effective factor for the emergence of this difference. Because in our study the data obtained from companies in different sectors are evaluated, but in the De Grosbois'research, only the companies in the tourism sector were examined.

One of the results similar to the work of De Grosbois is performance measurement. In both studies, the least mentioned factor in companies' reports is the information about the results of the initiatives. One of the most controversial issues in public relations in general and corporate social responsibility practices in particular is in the area of measurement. This study also showed once again that although companies take various initiatives to create value for society, they are weak in measuring their outcomes. The values for the measurement of performance in the sustainability areas of the companies examined have always remained at the lowest levels. Therefore, companies should not only make an initiative, but also measure the contribution of this initiative to the society and share the results.

The study has some limitations. First, the study was carried out of the top 100 companies with the highest revenue in Turkey. Second, the research is limited to the information obtained from the sustainability reports shared by the companies on their web pages. The research limitations and empirical findings provide opportunities for future research. Therefore, it is possible to increase the number of samples to obtain more comprehensive data in future research. This research can also be expanded to include different countries or lists and this way the results can be compared. In addition, the research method can be extended. Because in this study, content analysis method was used. For example, more detailed data can be obtained via interviewing company managers. 


\section{REFERENCES}

Aggarwal, P. (2013). Sustainability reporting and its impact on corporate financial performance: A literature review. Indian Journal of Commerce and Management Studies, 4(3), 51.

Akgül, U. (2010). Sustainable Development: Action Field of Applied Anthropology. Ankara University Faculty of Letters Anthropology Journal, 24, 133-164.

Al Matarneh, G. F. (2019). The Impact of Sustainability Dimensions in Improving the Quality of Financial Disclosure of Jordanian Shareholding Industrial Companies from the Point of View of External Jordanian Auditors. International Journal of Academic Research in Accounting, Finance and Management Sciences, 9(3).

Alshehhi, A., Nobanee, H., \& Khare, N. (2018). The impact of sustainability practices on corporate financial performance: Literature trends and future research potential. Sustainability, 10(2), 494.

Asuquo, A. I., Dada, E. T., \& Onyeogaziri, U. R. (2018). The Effect of Sustainability Reporting on Corporate Performance of Selected Quoted Brewery Firms in Nigeria. International Journal of Business \& Law Research, 6(3), 1-10.

Atağan, G. (2017). Sustainability Reporting Versus Integrated Reporting: BIST Sustainability Index . (New Trends in Finance and Accounting (Kitabı İçinde). (Ed: David Procházka). Springer: Switzerland.

Bertotto, B. B., Pohlmann, M., \& da Silva, F. P. (2014). The dimensions of sustainability: concepts and strategies in the textile and clothing supply chain in Brazil. Sustainable Design and Manufacturing 218-229.

Binark, M.(2014). Yeni Medya Çalışmalarında Araştırma Yöntem ve Teknikleri. Ayrıntı Yayınları: İstanbul.

Bonsón, E.\& Bednárová, M. (2015). CSR Reporting Practices of Eurozone Companies. Revista de Contabilidad, 18(2), 182-193.

Cahyandito, M. F., \& Ebinger, F. (2005). The Effectiveness of Sustainability Reporting: Is It Only About The Report's Design And Content. Available at SSRN 1670702.

Choi, S., \& Ng, A. (2011). Environmental and economic dimensions of sustainability and price effects on consumer responses. Journal of business ethics, 104(2), 269-282.

Clarissa, S. V., \& Rasmini, N. K. (2018). The Effect of Sustainability Report on Financial Performance with Good Corporate Governance Quality as a Moderating Variable.

Caradonna, J. L. (2014). "Sustainability A History. Oxford University Press. New York

Cozzio, C. (2019). The concept of sustainability in hotel industry: current dominant orientations and future issues. International Journal of Sustainable Development, 22(1/2),61-87.
Çalışkan, A. Ö.(2014). How Accounting and Accountants May Contribute in Sustainability?. Social Responsibility Journal, 10(2), 246-267.

da Costa Maynard, D., Vidigal, M. D., Farage, P., Zandonadi, R. P., Nakano, E. Y., \& Botelho,

R. B. A. (2020). Environmental, Social and Economic Sustainability Indicators Applied to Food Services: A Systematic Review. Sustainability, 12(5), 1804.

Dagilienè, L. (2014). Impact of Normative Institutional Factors on Sustainability Reporting. International Journal of Economics and Management Engineering, 8(6), 1659-1664.

De Grosbois, D. (2016). Corporate Social Responsibility Reporting in The Cruise Tourism Industry: A Performance Evaluation Using A New Institutional Theory Based Model. Journal of Sustainable Tourism, 24(2), 245-269.

Diesendorf, M., 2000, 'Sustainability and sustainable development', in Dunphy, D, Benveniste, J, Griffiths, A and Sutton, $P$ (eds) Sustainability: The corporate challenge of the 21st century, Sydney: Allen \& Unwin, chap. 2, 19-37.

Erdoğan, İ. (2007). Pozitivist Metodoloji: Bilimsel Araştırma Tasarımı, İstatistiksel Yöntemler, Analiz ve Yorum (2.baskı). Erk Yayınları: Ankara.

Farneti, F. \& Guthrie, J. (2009). Sustainability Reporting by Australian Public Sector Organisations: Why They Report. In Accounting Forum, 33(2), 89-98.

Fischer, D., Brettel, M. \& Mauer, R. (2020). The three dimensions of sustainability: a delicate balancing act for entrepreneurs made more complex by stakeholder expectations. Journal of Business Ethics, 1-20.

Gavana, G., Gottardo, P., \& Moisello, A. M. (2017). Sustainability Reporting in Family Firms: A Panel Data Analysis. Sustainability, 9(1), 38.

Gray, R. \& Milne, M. (2002). Sustainability Reporting: Who's Kidding Whom?. Chartered Accountants Journal of New Zealand, 81(6), 66-70.

Greco, G., Sciulli, N.\& D’Onza, G. (2015). The Influence Of Stakeholder Engagement On Sustainability Reporting: Evidence From Italian Local Councils. Public Management Review, 17(4), 465-488.

Herremans, I. M., Nazari, J. A., \& Mahmoudian, F. (2016). Stakeholder Relationships, Engagement, And Sustainability Reporting. Journal of Business Ethics, 138(3).

Herzig, C. \& Schaltegger, S. (2006). Corporate Sustainability Reporting. An Overview. Sustainability Accounting And Reporting kitabı içinde (sayfa. 301-324). Eds. Stefan Schaltegger, Martin Bennett ve Roger Burritt. Springer: The Netherlands.Dordrecht. 
Høgevold, N. M., Svensson, G., Klopper, H. B., Wagner, B., Valera, J. C. S., Padin, C. \& Petzer, D. (2015). A triple bottom line construct and reasons for implementing sustainable business practices in companies and their business networks. Corporate Governance.

Ketschau, T. J. (2017). Social sustainable development or sustainable social development-two sides of the same coin? the structure of social justice as a normative basis for the social dimension of sustainability. International Journal of Design \& Nature and Ecodynamics, 12(3), 338-347.

Kolk, A. (2010). Trajectories Of Sustainability Reporting By MNCs. Journal of World Business, 45(4), 367-374.

Kuşat, N. (2012). Organizational sustainability for sustainable corporations and its endogenous determinants. Afyon Kocatepe University Journal of Economics and Administrative Sciences, 14(2).

Laskar, N., Chakraborty, T. K. \& Maji, S. G. (2017). Corporate sustainability performance and financial performance: Empirical evidence from Japan and India. Management and Labour Studies, 42(2), 88-106.

Lu, W.\& Taylor, M. E. (2016). Which factors moderate the relationship between sustainability performance and financial performance? A meta-analysis study. Journal of International Accounting Research, 15(1), 1-15.

Mussari, R. \& Monfardini, P. (2010). Practices Of Social Reporting in Public Sector And Non-Profit Organizations: An Italian Perspective. Public Management Review, 12(4).

Nnamani, J.N., Onyekwelu, U.L. \&Ugwu, O.K. (2017) Effect of sustainability accounting and reporting on financial performance of firms in Nigeria brewery sector. European Journal of Business and Innovation Research, 5(1): 1-15

Reddy, T. L.\& Thomson, R. J. (2015). Environmental, social and economic sustainability: implications for actuarial science. University of the Witwatersrand, School of Statistics and Actuarial Science.
Rixon, D. (2010) Stakeholder Engagement in Public Sector Agencies: Ascending the Rungs of the Accountability Ladder. International Journal of Public Administration, 33(7).

Székely, F. \& Knirsch, M. (2005). Responsible leadership and corporate social responsibility: Metrics for sustainable performance. European Management Journal, 23(6), 628-647.

Sumaryati, A., \& Rohman, A. (2019). The Influence of Sustainability Reporting on Environmental and Financial Performance. Calitatea, 20(171), 131-134.

Şen, H.; Kaya, A. \& Alpaslan, B. (2018). A Historical and Current Perspective on Sustainability. Journal of Economic Approach, 29(107): 1-47.

Tarigan, J.\& Semuel, H. (2014). Pengungkapan sustainability report dan kinerja keuangan. Jurnal Akuntansi dan Keuangan, 16(2), 88-101.

Van Marrewijk, M. (2003). Concepts And Definitions of CSR and Corporate Sustainability: Between Agency And Communion. Journal of Business Ethics, 44(2-3), 95-105.

World Business Council for Sustainable Development (WBCSD). (2002). "Sustainable development reporting: String the balance". http://docs.wbcsd.org/2002/12/SustainableDevReporting-StrikingTheBalance.pdf (Accessed on 11.12.2019).

World Commission on Environment and Development (WCED). (1987). Our Common Future. Oxford University Press: New York, NY, USA.

Weber, O. (2017). Corporate sustainability and financial performance of Chinese banks. Sustainability Accounting, Management and Policy Journal, 8(3), 358-385.

Whetman, Lancee L. (2017). The Impact of Sustainability Reporting on Firm Profitability. Undergraduate Economic Review, 14(1).

Global Reporting Initiative (GRI), https://www.globalreporting.org/information/sustainability-reporting/Pages/ default.aspx (Accessed on. 10.12.2019). 